\title{
O TRABALHO DO PROFESSOR DE FRANCÊS COMO LÍNGUA ESTRANGEIRA: UM ESTUDO SOBRE AS RELAÇÕES ENTRE AS PRESCRIÇÕES E O QUE DIZEM OS PROFESSORES SOBRE SEU TRABALHO
}

\author{
EL TRABAJO DEL PROFESOR DE FRANCÉS COMO LENGUA EXTRANJERA: \\ UN ESTUDIO SOBRE LAS RELACIONES ENTRE LAS PRESCRIPCIONES Y LO \\ QUE DICEN LOS PROFESORES SOBRE SU TRABAJO
}

\begin{abstract}
THE WORK OF THE FRENCH AS A FOREIGN LANGUAGE TEACHER: A STUDY ON THE RELATIONSHIP BETWEEN PRESCRIPTIONS AND WHAT THE TEACHERS SAY ABOUT THEIR WORK
\end{abstract}

\author{
Marcos da Costa MENEZES ${ }^{1}$ \\ Eliane Gouvêa LOUSADA ${ }^{2}$
}

RESUMO: Este artigo tem como objetivo discutir as relações entre os documentos que orientam o trabalho de professores de francês e o que os próprios professores dizem sobre sua atividade docente. O quadro teórico que embasa as discussões é o do Interacionismo Sociodiscursivo (BRONCKART, 2008), assim como teorias que auxiliam na compreensão do trabalho, como a Ergonomia da Atividade (SAUJAT, 2004) e a Clínica da Atividade (CLOT, 2008). A compreensão da relação entre os documentos e a atividade docente se dará pela análise de textos escritos (documentos) e orais (entrevistas).

PALAVRAS-CHAVE: Trabalho docente. Interacionismo sociodiscursivo. Formação de professores.

RESUMEN: El objetivo de este artículo es discutir las relaciones entre los documentos que orientan el trabajo de los profesores de francés y lo que los propios profesores dicen sobre su actividad docente. El marco teórico que fundamenta las discusiones es el Interaccionismo Sociodiscursivo (BRONCKART, 2008), así como teorías que auxilian en la comprensión del trabajo, como la Ergonomía de la Actividad (SAUJAT, 2004) y la Clínica de la Actividad (CLOT, 2008). La comprensión de la relación entre los documentos y la actividad docente se dará por el análisis de textos escritos (documentos) y orales (entrevistas).

PALABRAS CLAVE: Trabajo docente. Interaccionismo sociodiscursivo. Formación de profesores.

\footnotetext{
${ }^{1}$ Universidade de São Paulo (USP), São Paulo - SP - Brasil. Mestre em Letras pela Faculdade de Filosofia, Letras e Ciências Humanas. E-mail: quihno@yahoo.com.br

${ }^{2}$ Universidade de São Paulo (USP), São Paulo - SP - Brasil. Professora-doutora do Departamento de Letras Modernas da Faculdade de Filosofia, Letras e Ciências Humanas (FFLCH). E-mail: elianelousada@uol.com.br.
} 
ABSTRACT: This article aims to discuss the relationships between the documents that guide the work of French teachers and what teachers themselves say about their teaching activity. The theoretical framework that underlies the discussions is that of Sociodiscursive Interactionism (BRONCKART, 2008), as well as theories that help in the understanding of work, such as Ergonomics of Activity (SAUJAT, 2004) and Clinic of Activity (CLOT, 2008). The understanding of the relationship between the documents and the teaching activity will be through the analysis of written texts (documents) and oral (interviews).

KEYWORDS: Teacher's work. Socio-discursive interactionism. Teacher development.

\section{Introdução}

No quadro das pesquisas sobre o trabalho docente, interessamo-nos em estudar como os professores de língua estrangeira, em nosso caso o francês, realizam seu trabalho em contextos escolares públicos (ligados à Universidade ou a escolas públicas) a partir das orientações que recebem para fazê-lo, como se veem enquanto professores e como veem seu trabalho. Com o intuito de oferecer cursos de línguas acessíveis à população em geral, os centros de línguas públicos são um importante local para que os professores (e às vezes alunos e futuros professores) se formem pela prática, ou seja, no e pelo trabalho. No caso dos cursos de extensão universitária, muitas vezes, os professores têm um vínculo com a universidade, pois são estudantes de licenciatura ou pós-graduação e optam por começar a ensinar naquele contexto para poderem aprender seu trabalho exercendo-o e sofrendo menos pressões do que se estivessem em uma escola particular de línguas. É no contexto de um curso de extensão universitária de francês que temos realizado uma série de pesquisas sobre o trabalho educacional, a formação de professores e a aprendizagem do trabalho docente. Esses estudos são realizados pelos membros do Grupo ALTER-AGE-CNPq e têm gerado muitos dados coletados de forma longitudinal, além de ter sido objeto de pesquisas de mestrado, doutorado e inúmeras publicações.

Neste artigo, apresentaremos uma das pesquisas desenvolvidas no contexto mencionado, cujo objetivo central é discutir como os documentos que prescrevem a atividade docente têm relação com o trabalho do professor. Partimos das prescrições que orientam o trabalho docente e, posteriormente, nos atemos a verificar também o que o professor fala de seu próprio trabalho para, então, estabelecermos uma relação entre os documentos prescritivos e a percepção do professor sobre sua própria atividade profissional. 
O quadro teórico que embasa nossas discussões é o do Interacionismo Sociodiscursivo - doravante ISD (BRONCKART, 1999, 2006, 2008; MACHADO, 2009), que nos dá um aparato teórico para que possamos discutir o trabalho e sua relação com a linguagem, assim como nos fornece também um modelo de análise de textos: o modelo de arquitetura textual desenvolvido por Bronckart (1999, 2006, 2008). Além do ISD, apoiamo-nos também em teorias que estudam o trabalho docente, mais precisamente a Ergonomia da Atividade (AMIGUES, 2002, 2004; SAUJAT, 2002, 2004) e a Clínica da Atividade (CLOT, 1999, 2001, 2008; FAÏTA, 2011). Tais teorias nos fornecem subsídios para discutir o trabalho docente de um ponto de vista que considera: a atividade docente como um trabalho, o papel central que as prescrições têm no trabalho do professor, a importância das verbalizações feitas pelos próprios trabalhadores sobre sua atividade ${ }^{3}$. Tanto a Ergonomia da Atividade quanto a Clínica da Atividade cooperam para a compreensão do trabalho docente em conformidade com as análises de textos feitas com o modelo de arquitetura textual, uma vez que tais teorias, assim como o ISD, são oriundas dos estudos feitos por Vigotski (1927, 1999), sobretudo os que se referem ao agir humano e às questões relacionadas ao desenvolvimento.

Como dissemos, as discussões contidas neste artigo foram fomentadas a partir de uma pesquisa longitudinal realizada com professores de francês atuando em cursos de extensão. De maneira mais específica, os dados que traremos aqui são oriundos de uma pesquisa de mestrado desenvolvida naquele contexto, na qual se estudou os documentos prescritivos e as verbalizações de dois professores de francês como língua estrangeira (FLE) a respeito de sua própria atividade ${ }^{4}$. No que se refere à metodologia, três etapas se fizeram necessárias para que o estudo pudesse ser realizado, a saber: 1. Pesquisa de documentos e coleta de dados; 2. Análise dos textos dos documentos e constituição de um coletivo de trabalho; 3. Entrevistas com os dois professores voluntários em nossa pesquisa e discussões. Posteriormente a essas etapas, os textos dos documentos e das entrevistas foram analisados a partir do modelo de arquitetura textual proposto por Bronckart $(1999,2006,2008)$ e interpretados à luz das teorias que estudam o trabalho docente.

Neste artigo, procuraremos responder a três perguntas:

\footnotetext{
${ }^{3}$ Todos os pontos aqui mencionados serão tratados com maior profundidade na seção 2, na qual expomos com mais detalhes o quadro teórico que embasa as discussões.

${ }^{4}$ MENEZES, M. C. O trabalho do professor e as prescrições feitas por organismos governamentais e estabelecimentos de ensino. 2015. 246p. Dissertação (Mestrado). Faculdade de Filosofia, Letras e Ciências Humanas da Universidade de São Paulo. São Paulo, 2015.
} 
1. Com quais orientações, implícitas e explícitas, se deparam os dois professores de FLE em seus respectivos contextos de trabalho?

2. Como esses professores veem a si mesmos enquanto docentes? E como veem seu próprio trabalho?

3. Qual a relação entre o que está prescrito nos documentos e a forma como esses professores veem a si mesmos e a seu próprio trabalho?

O caminho que nos levará às nossas conclusões e às respostas a essas perguntas passa por alguns pontos. Primeiramente, apresentaremos os pressupostos teóricos que embasam nossas discussões e nos concentraremos em explicitar conceitos importantes para que possamos fundamentar o que será discutido.

\section{Pressupostos teóricos}

Muitos dos estudos feitos a respeito do trabalho docente têm como objeto de pesquisa a atividade de ensino, procurando verificar de que forma(s) os alunos aprendem mais e melhor, quais são as estratégias usadas pelos professores para tenir la classe $^{5}$, entre outras preocupações inerentes ao trabalho. Amigues (2003) pontua que a lógica que considera o saber, o professor e o aluno está dentro de uma perspectiva de processo-produto, uma vez que se verifica o trabalho (processo), mas foca-se também, e, muitas vezes bastante, a aprendizagem do aluno (produto).

Um dos conceitos fundamentais para o estudo do trabalho é o de trabalho prescrito, trabalho realizado e, para algumas das ciências do trabalho, o de real da atividade. Bronckart (2008) pontua que as prescrições que orientam o agir humano no trabalho podem estar colocadas em forma de esquemas, quadros, tipificações. Para o autor, existem diversas formas pelas quais tais textos podem ser chamados, tais como “textos prescritivos, injuntivos, procedimentais, de incitação à ação" (BRONCKART, 2008, p. 127), sendo que eles podem ser considerados o primeiro lugar possível de morfogênese da ação. Os textos que orientam o trabalho do professor possuem algumas características mencionadas por Adam (2001) e retomadas por Bronckart (2008). Em primeiro lugar, o enunciador de tais textos é sempre um expert não mencionado diretamente; outro ponto notável é que o destinatário de tais textos é referenciado de forma genérica, e não de forma direta; por fim, Bronckart (2008) observa que tais textos propagam um 'contrato de felicidade', no qual está implícito que, se o trabalhador seguir o que está sendo preconizado, alcançará o sucesso em seus intuitos.

${ }^{5}$ Expressão francesa que significa, grosso modo, manter a gestão da sala de aula. 
O trabalho realizado, por sua vez, constitui-se no que o trabalhador realmente faz a partir do que lhe é prescrito. Clot (2001) esclarece que essa parte realizada é apenas uma entre as várias possibilidades de ação em um determinado momento. Ele considera também que há uma parte do trabalho docente que não é visível chamada real da atividade, que comporta aquilo que não foi feito, aquilo que foi pensado, mas não realizado ou mesmo as possibilidades que não se concretizaram. Clot (1999) baseia-se em Vigotski (1997) para afirmar que o real da atividade é composto pelos comportamentos que venceram, mas também pelos que não foram realizados, que foram preteridos. O conceito de real da atividade constitui, assim, uma dimensão subjetiva do trabalho.

Para os pesquisadores da Clínica da Atividade, o real da atividade só pode emergir e ser compreendido por meio das verbalizações dos trabalhadores a respeito de seu trabalho. Essas verbalizações que permitem a emergência do real da atividade fazem com que a experiência vivida se torne um meio para viver outras experiências, contribuindo para o desenvolvimento dos sujeitos e do próprio trabalho. Dito de outra forma, para Clot (1999), o diálogo é o motor do desenvolvimento, por isso, as verbalizações sobre $\mathrm{o}$ trabalho também são uma forma de desencadear $\mathrm{o}$ desenvolvimento dos trabalhadores e da própria situação de trabalho, gerando transformações. Nesse intuito, a Clínica da Atividade e a Ergonomia da Atividade desenvolveram métodos de intervenção no trabalho, como a instrução ao sósia e a autoconfrontação, que permitem criar verbalizações sobre a situação de trabalho.

De acordo com Clot (1999, 2001), a intervenção na situação de trabalho não pode ser feita junto a um só trabalhador/professor. Para ele, ao propor um método de intervenção, é necessário partir de um coletivo de trabalhadores, ou seja, não apenas um grupo de trabalhadores que atuem em um mesmo ambiente físico, mas que tenham interesses em comum. Em relação ao trabalho docente, a noção de coletivo de trabalho ganha uma importância particular, uma vez que, por vezes, os professores enfrentam dificuldades para colocar em prática as prescrições que lhe são passadas e, nesses casos, um coletivo de trabalho pode atuar cooperando para que a reconcepção de tais prescrições seja algo partilhado, de comum acordo (AMIGUES, 2002). O coletivo de trabalho pode também servir de apoio a colegas que não conseguem atuar com determinadas demandas, por exemplo. Ao relacionar o coletivo de trabalho ao processo de intervenção que nele é executado, Clot (1999) considera que só o coletivo de trabalho é capaz de trazer transformações duráveis para a situação de trabalho. 
No que se refere aos métodos de intervenção nas situações de trabalho, interessanos explicitar neste artigo somente a que foi utilizada em nossa pesquisa: a entrevista de instrução ao sósia. Desenvolvida por Oddone no contexto de formação de trabalhadores da empresa Fiat na década de 1970 (ODDONE et al, 1981), o método leva o trabalhador a falar sobre sua atividade projetando-a em um futuro hipotético. Formado o coletivo de trabalho, o interveniente e o instrutor voluntário discutem sobre o trabalho a partir de determinadas regras. A entrevista inicia-se com a orientação do interveniente: "Suponhamos que eu seja seu sósia e que amanhã eu deva te substituir em seu trabalho. Quais são as instruções que você deveria me dar para que ninguém perceba a substituição?"6 (CLOT, 2001, p. 9). A orientação deve ser dada empregando a segunda pessoa do singular (tu ou você) e, enquanto o trabalhador instrui seu sósia, deve encorajá-lo a tratar das minúcias de sua atividade, sendo que para isso as questões colocadas devem estar baseadas sempre no como e jamais no porquê. A técnica de instrução ao sósia é considerada um processo de coanálise (SAUJAT, 2005), pois o trabalhador participa ativamente da análise de seu próprio trabalho por meio das etapas que se seguem. Findada a instrução, os demais trabalhadores presentes na sala podem fazer questões e comentários sobre o que ouviram. Ao fim da reunião, o trabalhador que fez a instrução ao sósia leva o áudio para casa e o ouve, em seguida, elabora um textocomentário que discuta algum ponto que lhe chamou a atenção e/ou lhe causou algum estranhamento. Na próxima reunião, também conhecida como retorno ao coletivo, fazse a leitura do texto-comentário trazido e todos os trabalhadores participantes podem tecer comentários a respeito do trecho escolhido.

Em nossa pesquisa, apoiamo-nos em um quadro teórico-metodológico que compartilha conceitos da Ergonomia da Atividade e Clínica da Atividade e, também, fornece um modelo de análise de textos: trata-se do Interacionismo Sociodiscursivo proposto por Bronckart (1999, 2006, 2007, 2008, 2013). Antes da análise textual propriamente dita, realizamos a análise do contexto de produção tal como proposto por Bronckart (1999), levantando hipóteses sobre o contexto físico e sociossubjetivo que deu origem ao texto, ou seja, levando em conta o emissor / enunciador e o receptor / destinatário do texto, o local físico e social em que se deu produção e circulação, assim como o momento de produção e circulação e os objetivos explícitos e implícitos do texto. Já o modelo de arquitetura textual ${ }^{7}$ é composto por três níveis:

${ }^{6}$ Tradução nossa.

${ }^{7} \mathrm{O}$ modelo que expomos aqui considera as modificações propostas por Bronckart em 2013. 
- A infraestrutura geral do texto: contém a organização temática (estrutura do texto, suas partes, a quantidade de parágrafos que ele contém, sua disposição gráfica, os temas abordados) e a organização discursiva (tipos de discurso que compõem o texto e como ele está articulado entre si);

- Os mecanismos de textualização: é composto pela análise das conexões e da coesão nominal presentes nos textos;

- Os mecanismos de responsabilização enunciativa: é onde pode ser encontrado o foyer enunciativo, ou seja, as vozes e pontos de vista e as atribuições modais.

Neste artigo, é o nível dos mecanismos de responsabilização enunciativa que nos interessa mais, principalmente no que se refere às vozes inseridas no texto, às escolhas lexicais que mostram o ponto de vista do enunciador e também às modalizações sobretudo a modalizações deônticas, que, nas palavras de Bronckart (1999), avaliam o que é enunciado à luz de valores sociais e podem ser de ordens diferentes, como a ordem do dever, da interdição etc.

Para completar nossas análises, sobretudo dos mecanismos enunciativos, servimo-nos de outros autores como, por exemplo, para a categoria da inserção de vozes. Por vezes, o enunciador faz colocações que não são necessariamente as suas, mas de instituições, instâncias sociais ou mesmo personagens. Nesse sentido, os estudos desenvolvidos por Authier-Revuz (1998) sobre a heterogeneidade constitutiva podem completar o modelo do ISD. Para a autora, é possível que haja em determinados textos uma não coincidência do dizer consigo mesmo. Para que se possa melhor compreender esses casos, é necessário ter em mente o fato de que determinado discurso é permeado por outros discursos, o chamado "já-dito dos outros discursos" (AUTHIER-REVUZ, 1998, p. 22). Cabe, portanto, a quem analisa tal discurso, a identificação de onde parte tal discurso que habita o discurso analisado. Essas categorias serão exemplificadas em nossas análises.

\section{Metodologia}

Inicialmente, planejávamos realizar a pesquisa estudando unicamente o trabalho dos professores que atuam nos Centros de Estudos de Línguas de São Paulo (doravante CEL), mas tal tentativa mostrou-se infrutífera devido a impedimentos diversos como a 
não participação de alguns professores. Diante desses impedimentos, propusemos a criação de um pequeno coletivo de trabalho que se formou pelo fato de ambos os professores terem interesses comuns e atuarem em situações semelhantes de trabalho. Fizeram parte do coletivo um professor de francês do CEL e uma professora de um curso de extensão de francês.

Os CEL são geridos pela Secretaria de Educação do Estado de São Paulo e funcionam dentro de algumas escolas estaduais. Oferecem cursos de inglês, francês, italiano, alemão e japonês a alunos da rede pública. Para estudar nos CEL, é necessário que os alunos estejam cursando a partir do sétimo ano do ensino fundamental, sendo que as aulas são frequentadas no contraturno do ensino regular. No que se refere aos professores, trata-se de docentes que atuam na rede estadual, sendo que muitos são contratados e sem vínculo de estabilidade.

O outro contexto que faz parte da pesquisa são os cursos de extensão de francês de uma universidade pública que atendem um público variado: desde estudantes e professores da própria universidade até professores da rede pública de ensino fundamental, pessoas da terceira idade e interessados em geral. Sendo um curso livre, o pré-requisito para frequentá-lo é apenas ser maior de 18 anos e ter ensino médio completo. No que diz respeito aos professores que aí atuam, eles têm o estatuto de professores-monitores, uma vez que não se tratam de funcionários da faculdade, mas de profissionais que recebem uma bolsa para atuar no ensino de FLE. Os requisitos para ser um professor-monitor dos Cursos Extracurriculares são: ter um diploma de graduação, possuir vínculo com a universidade - seja na graduação ou pós-graduação -, assim como passar por um processo seletivo aberto por meio de edital.

\section{Pesquisa documental}

Por meio de pesquisa documental na internet chegamos a um primeiro documento a ser analisado: a Resolução da Secretaria de Educação no 70 de 26 de outubro de 2010 (doravante Resolução SE). O documento não é endereçado somente aos professores de línguas estrangeiras, mas, vale ressaltar que as duas únicas línguas estrangeiras que contêm seção direta são o inglês e o espanhol. Para as demais línguas oferecidas nos CEL, o leitor é orientado a considerar o que está colocado para o professor de espanhol. 
O segundo documento escolhido para compor nossas análises foi o Cadre Européen Commun de Références (doravante CECR). Levamos em consideração esse documento a partir do momento em que, na etapa preliminar da pesquisa (de incursão aos CEL), conversamos com uma professora de francês que, mencionou o CECR como um documento que ela levava em consideração para orientar seu trabalho. Esse documento, mesmo que não se pretenda prescritivo, é usado como referência para elaboração de exames e material didático no mundo todo, o que lhe confere significativa importância.

O terceiro documento que compõe a pesquisa é o Guide du Moniteur. Em relação aos outros documentos que compõem a pesquisa, consideramos que o Guide $d u$ Moniteur é o menos genérico, já que ele foi elaborado com o intuito de auxiliar os professores-monitores em sua atuação quotidiana nos Cursos de Extensão de Francês.

O olhar que lançamos sobre os documentos não procura verificar o que é falado sobre o ensino de FLE. Mesmo nos documentos que se mostram mais genéricos, nosso intuito foi o de procurar e considerar para análise somente o que se referia ao trabalho do professor. Sendo assim, da Resolução SE e do CECR foram selecionados trechos específicos que tratam do trabalho docente. Em relação ao Guide du Moniteur, seu caráter contextual nos levou a analisá-lo inteiro, uma vez que as orientações para o trabalho dos professores-monitores é algo que perpassa o documento inteiro.

\section{Constituição do coletivo de trabalho}

Como mencionamos anteriormente, as verbalizações sobre o trabalho devem se dar em um coletivo de trabalho, tendo este o intuito de amparar o trabalhador que, por vezes, exporá suas dificuldades, angústias e frustrações em relação ao seu métier. O que se mostrou dificultoso em relação aos nossos objetivos iniciais foi justamente a constituição desse coletivo em um lugar onde ele não existia: os CEL. Considerada essa impossibilidade, convidamos o único professor que se mostrou interessado, o professor J, para compor um coletivo de trabalho e optamos por associá-lo a outra professora dos Cursos de Extensão, também fazendo parte do contexto da pesquisa.

A professora convidada dos cursos de extensão tinha características semelhantes às do professor $\mathbf{J}$ em relação ao tempo de ensino no francês e se interessava também pela própria formação, assim como tinha disponibilidade para participar das reuniões. Observadas tais características, formou-se um pequeno coletivo constituído pela a 
professora $\mathrm{C}$, o professor $\mathrm{J}$ e o pesquisador. As primeiras reuniões - que chamamos de reuniões preliminares - ocorreram para que os professores fossem apresentados e, posteriormente, expusessem as dificuldades vivenciadas nas situações de trabalho (tais reuniões foram registradas em áudio).

\section{Entrevistas de instrução ao sósia}

As entrevistas de instrução ao sósia ocorreram em duas etapas. Na primeira, os professores consideraram uma aula hipotética para instruir o sósia e, finalizadas as instruções com os dois professores, houve um tempo para que fossem feitos comentários, questões e esclarecimentos. Terminada a reunião, cada professor teve um tempo para escutar o áudio registrado e, após algumas semanas, foi marcada a reunião de retorno ao coletivo com o intuito de discutirmos pontos que os professores escolheram daquilo que eles mesmos instruíram. Nesse mesmo dia, ficou decidido, a critério dos professores, que seria feita mais uma instrução ao sósia.

$\mathrm{Na}$ segunda etapa das instruções ao sósia, os professores decidiram tratar de um tema que muito lhes interessava: a preparação de uma aula. Com exceção do tema, os procedimentos usados na segunda instrução ao sósia foram iguais aos da primeira tempo para discussões no dia da entrevista de instrução ao sósia, registro em áudio levado e escutado pelos professores em casa e reunião de retorno ao coletivo.

\section{Transcrição e análise dos dados}

Os dados produzidos nas duas instruções ao sósia realizadas foram transcritos com base nas normas do projeto NURC da USP. A análise dos dados, tanto dos documentos prescritivos quanto das instruções ao sósia, foi feita levando em consideração o modelo de arquitetura textual desenvolvido por Bronckart (1999, 2006, 2008, 2013). Neste artigo, visando responder as perguntas colocadas na introdução, mostraremos os resultados da análise que concernem somente ao contexto de produção, ao nível dos mecanismos de responsabilização enunciativa - a inserção de vozes, as modalizações deônticas e escolhas lexicais feitas pelo agente-produtor.

\section{Resultados das análises}

\section{Análise dos documentos}


Concernente ao contexto de produção da Resolução SE, o lugar físico e social não são marcados no texto, mas sabe-se que o documento foi elaborado pela Secretaria de Educação do Estado de São Paulo, que tem importância administrativa e política. Em relação ao lugar de circulação, o documento está disponível na internet, o que lhe confere uma acessibilidade para todos os interessados. O documento data de 26 de outubro de 2010 e o emissor empírico é apagado no texto, mas o enunciador oficial é o secretário de Educação do Estado de São Paulo, que assume uma voz administrativa para divulgar a resolução. Quanto ao receptor/destinatário, o texto destina-se aos professores que atuam ou desejam atuar no ensino público, mais precisamente no ensino básico II $^{8}$. O objetivo do texto analisado é divulgar os perfis profissionais, as competências e habilidades exigidas dos professores de todas as áreas do ensino básico II da rede estadual, sendo que tal perfil será requerido nos exames, concursos e processos seletivos promovidos pela Secretaria de Educação.

O lugar físico de produção do CECR é Strasbourg. Em relação ao lugar social, nota-se o caráter institucional com valor político, visto que o documento foi criado pensando-se na integração entre as diferentes nações europeias. O local de circulação é a internet, onde o documento pode ser facilmente consultado em várias línguas. O ano de 2001 é marcadamente o momento de produção do documento. O emissor empírico não é explicitado no texto, mas sabe-se que o enunciador oficial é o Conselho da Europa através de vários grupos e comissões formadas para chegar à versão final do documento. Os receptores e destinatários são todos os interessados em ensino e aprendizagem de línguas estrangeiras, quer sejam aprendizes, professores ou mesmo instituições de ensino. $\mathrm{O}$ excerto que analisamos tem como objetivo propor uma reflexão sobre os papéis dos professores, aprendizes e dos suportes utilizados para o ensino e aprendizagem de língua francesa.

O Guide du Moniteur, por sua vez, tem como lugar físico de produção uma faculdade de Letras de São Paulo, já como lugar social é cabível mencionar que se trata de uma universidade pública. O lugar de circulação do documento é a internet. Quanto ao momento de produção, vale mencionar que a versão usada em nossas análises é a atualizada em agosto de 2013. O emissor empírico também é apagado no texto, mas por meio de algumas marcas deixadas podemos verificar que se trata de pessoas que fazem parte do grupo de professores-monitores. Percebe-se que o enunciador é um professor-

${ }^{8}$ Corresponde ao ensino fundamental II, comportando do $6^{\circ}$ ano $9^{\circ}$ ano. 
monitor mais experiente que dá orientações aos recém-chegados. No que se refere aos receptores e destinatários, são considerados todos os que ingressam como monitoresprofessores de língua francesa nos Cursos de Extensão. Em relação aos objetivos, percebemos que há um objetivo explícito: instruir os novos professores-monitores em tudo o que concerne à sua atividade. Porém, há igualmente um objetivo implícito, que é fazer com que os novos monitores ajam conforme o procedimento vigente.

No trecho da Resolução SE selecionado para análise, notamos que o agenteprodutor insere alguns índices de vozes que diferem daquilo que se esperaria dele. Identificamos a voz da sociologia ao percebermos a menção de certos aspectos inerentes à realidade social e política brasileira, ao papel social do professor, às políticas públicas para a educação, à cultura geral e conhecimento cultural difundido na sociedade, à escola inclusiva, às novas demandas da sociedade do conhecimento, entre outros. Percebe-se também a voz da pedagogia, voz esta que se refere ao ensino de maneira mais generalizada, sem pontuar aspectos pontuais das diferenças entre séries e disciplinas, tocando ainda temas relacionados à transposição didática, contrato didático, planejamento, gestão de classe, avaliação de aprendizagem, relação professor-aluno, gestão de sala de aula e desníveis de aprendizagem numa mesma sala. Outra voz percebida é uma voz institucional, que situa a educação básica num sistema dividido (sistema de ensino estadual, sistema de ensino municipal) e que dialoga com outras instâncias (MEC, secretarias de educação, conselhos de educação).

Em relação ao trecho analisado do CECR, a voz predominante inserida é a da didática de línguas. Mesmo havendo essa voz num documento que tem caráter e importância institucional e política, verificamos que são evocadas correntes diferentes da didática de línguas, o que parece conferir ao texto uma diversidade de posicionamentos. Em relação a essas correntes da didática de línguas, temos a associação de aprendizado com trabalho, o papel e postura do professor, a diversificação no ensino, assim como a preocupação com o modo de aprendizagem dos alunos. Sabese, desde a introdução do documento, que em sua elaboração houve cooperação de diferentes equipes. É compreensível, portanto, a abrangência de vozes inseridas por vocabulário(s) específico(s) oriundo(s) de teorias diferentes, uma vez que o documento se pretende genérico e instaurador de discussões.

No Guide du Moniteur, notamos que existem índices que apontam a presença da voz da experiência, ou seja, uma voz que tem conhecimento a respeito do que trata e tem consciência dos direitos e deveres dos professores-monitores (le personnel chargé 
du nettoyage et de la surveillance du bâtiment ne sont pas nos employés); é também conhecedora de alguns problemas (Cette fermeture [des amoires] est essentielle pour éviter des problèmes tels que la disparition de matériel qui pourrait avoir une conséquence sur vous). Há também a presença da voz do professor experiente, com prática instituída (C'est toujours intéressant de connaître le parcours des élèves en tant qu'étudiants de français). A voz da instituição de ensino aparece como uma voz de fundo que permeia todo o documento, uma vez que as regras estabelecidas são as próprias regras da universidade. Por outro lado, há também uma voz que legitima a atividade dos professores-monitores em relação ao lugar ocupado pelos Cursos Extracurriculares (Vous avez le droit d'utiliser les salles multimédia du bâtiment de Lettres).

As modalizações deônticas da ordem do dever fazem referência à formação do professor (A formação de professores deve assegurar a aquisição de conhecimentos sobre o desenvolvimento humano), a ações que o professor deve adotar em relação aos pares ([...] explicar como a escola e o professor devem agir para adequar o ensino e promover a aprendizagem), assim como ações requeridas de alunos também (propor sequências didáticas de sua disciplina, nas quais sejam explicitadas e explicadas o que o aluno deverá aprender com a situação proposta).

O CECR também possui algumas modalizações deônticas da ordem do dever explicitadas pelos trechos "Il faut prendre en considération" e "les enseignantes doivent se rendre compte". Por vezes, porém, o agente-produtor do texto parece não estar certo de qual verbo usar em suas construções, como percebemos em "Quelles proportions différentes du temps du cours peuvent (doivent) être consacrées", e essa alternância do uso dos verbos pouvoir e devoir pode denotar certo cuidado do enunciador em relação à recepção do texto pelos destinatários, uma vez que, como já foi dito, o documento não se pretende prescritivo.

No Guide du Moniteur, por sua vez, as modalizações deônticas da ordem do dever são construídas com o verbo devoir (votre documentation doit être réglée le plus tôt possible), ou mesmo o verbo falloir (il faut les rendre [les clés] quand vous ne serez. plus moniteur). Vale explicitar, no entanto, que o documento possui modalizações deônticas que estão também na ordem da permissão - uso do verbo pouvoir (vous pouvez contacter toujours notre coordinatrice), assim como modalizações deônticas que estão na ordem da interdição (il ne faut jamais déranger les activités et les horaires de la faculté). 
Algumas escolhas lexicais feitas pelo agente-produtor da Resolução SE se constituem como um ponto importante a ser notado, já que mostram uma tomada de posição por parte dele. Podemos verificar que o agente-produtor percebe o trabalho do professor como complexo e diversificado (trabalho diversificado; situações educativas e de ensino complexas), mas que tem importância social (papel social do professor) e que a planificação (conteúdo previsto no plano de trabalho; planos de ensino dos professores) e a formação (a formação de professores deve assegurar) são partes constitutivas desse trabalho.

No CECR, por sua vez, algumas escolhas lexicais mostram pontos valorizados pelo agente-produtor, mesmo que estejam colocadas em questionamentos. Chama-nos a atenção termos como importance e capacité usados no trecho "Quelle importance accorder: à la capacité à faire de la recherche et à prendre ses distances; capacité à la mettre en oeuvre [l'évaluation]; capacité de l'enseigner [le socioculturel, la littérature]; capacité à individualiser l'enseignement [avec des apprenants dont le mode d'apprentissage et les aptitudes sont différents]", assim como o termo automonie presente nos sintagmas "grande autonomie, manière autonome".

O Guide du Moniteur contém algumas escolhas lexicais que chamam nossa atenção. O termo attention, por exemplo, é empregado em diversos trechos no intuito de mostrar a importância da informação dada. Alguns sintagmas, por sua vez, são propositadamente reforçados com adjetivos, como vemos em "fermeture essentielle". Escolhas como "vous avez le droit d'utiliser e qui vous assure une réduction de prix" denotam a consciência de uma legitimidade em relação às possibilidades na universidade e fora dela. Em certo ponto, o agente-produtor mostra por meio de escolhas lexicais que o grupo de professores-monitores que atua nos Cursos de Extensão é um grupo que se ajuda e que compartilha atividades (nous comptons sur la collaboration de tous les moniteurs). Logo no início do documento, escolhas como "c'est avec un rand plaisir que nous vous recevons" mostram também a cordialidade do grupo de professores-monitores que já atuam nesse contexto de trabalho. Além disso, a seriedade do curso também é mostrada com escolhas como "on n'accepte jamais d'auditeurs libres" e "la fréquence exigée (85\%)".

\section{Análise das entrevistas de instruções ao sósia}


O professor $\mathrm{J}$ insere, por meio do discurso direto, a voz de seus alunos e a voz da coordenação em suas verbalizações. Chama-nos particularmente a atenção a inserção da voz da coordenação pedagógica do CEL em que atua, já que ela vem carregada de um valor injuntivo, ou seja, porta uma prescrição: “il faut parler français". A voz do CECR também inserida no texto a partir do momento em que o professor evoca, por meio do léxico presente nesse documento, os níveis de ensino a serem seguidos pelos alunos no CEL, tais como a menção dos níveis A2 e B2, preconizados no documento em questão. De uma maneira indireta, o professor evoca a voz de seus colegas de trabalho, à qual se antepõe em relação a um posicionamento tomado - o de que os professores devem estar habituados a receber um baixo salário. O posicionamento do professor vai contra essa voz de seus pares, já que em sua refutação ele afirma "Je travaille bien, je suis un bon professeur et vais être bien payé". O próprio posicionamento do professor se configura como índice de inserção de outra voz: a voz da valorização do professor e de seu trabalho. A voz do governo também é percebida na verbalização feita pelo professor Jean quando ele relata o que geralmente os governantes pensam a respeito da atuação dos professores em relação aos alunos (c'est le prof qui n'a pas stimulé les élèves). Se no caso anterior tínhamos um índice da voz da valorização dos professores, neste caso, percebe-se um índice de inserção da voz de culpabilização dos professores.

Algumas escolhas lexicais feitas pelo professor podem ser consideradas também como índices de inserção de vozes. É o que vemos, por exemplo, na inserção da voz da falta, em que os termos manquer e abandonner denotam um desânimo do professor em relação às carências que ele percebe em seu contexto de trabalho (il nous manque toujours quelque chose [...] une chose [...] qui me donne envie d'abandonner ma profession). Por outro lado, percebe-se também que algumas escolhas lexicais indicam a inserção da voz da motivação, em que o professor, ao referir-se ao trabalho a ser exercido com os alunos, menciona que é necessário "captiver, gagner la salle, motiver les élèves".

A professora $\mathrm{C}$, por sua vez, insere a voz do coletivo de professores a que pertence, o que pode ser notado pelo emprego dos pronomes nous e on para referir-se a algumas atividades. Isso parece mostrar uma dimensão coletiva do trabalho, uma vez que seus pares são evocados por meio dessa voz coletiva. Em outros momentos, porém, é a voz da consciência da professora que é inserida, e se mostra povoada por outra voz: a da coordenação, que remete ao que ela precisa fazer (le contenu, le chronogramme... Erica va dire que c'est pas bon). Essa cobrança pode estar associada à inserção da voz 
do componente técnico, quando a professora faz referência a uma obrigação que se impõe: "je dois être technique". Esse componente técnico é posteriormente negado (c'est pas ça), e isso ocorre em uma das reuniões de retorno ao coletivo a partir de uma reflexão da professora em relação a seu modo de agir. A voz da eficácia no trabalho aparece, quando, ao falar sobre a preparação de aula para suas turmas e perceber sua sobrecarga de trabalho, menciona que deseja elaborar "un cours qui va servir à tous les publics". Há também a inserção da voz do professor iniciante, que aprende o métier, o que é percebido por meio de algumas escolhas lexicais feitas no trecho "on apprend à donner des cours... mais pas très expérient". Outra voz que nos chama particularmente a atenção é a voz das recentes abordagens dos estudos de línguas estrangeiras. O índice de inserção dessa voz também se dá pelas escolhas lexicais da professora, ao empregar o termo approche e construir a afirmação "c'est pas par la grammaire". O que nos chama a atenção é que tais teorias não estão necessariamente explicitadas nos documentos aos quais a professora teve acesso, mas certamente elas compõem um discurso que, por sua vez, faz parte da rede discursiva que permeia o trabalho do professor, conforme atestam Bronckart e Machado (2004).

As modalizações deônticas da ordem do dever já seriam esperadas nos textos de instrução ao sósia, já que nessa técnica o professor deve orientar o seu sósia a respeito do que ele deve fazer, portanto o uso do verbo dever não é uma surpresa. O que nos interessa, então, ao verificarmos tais modalizações, é analisar sobre quais ações elas incidem. Nas verbalizações do professor $\mathbf{J}$ as ações retratadas vão desde algumas relacionadas ao cotidiano (tu dois aller [au travail] en métro) até outras relacionadas a pontos específicos de seu trabalho, como o uso de equipamentos do CEL (tu dois vérifier les équipements) e o modo de tratar os alunos (il faut faire attention parce que les adolescentes parfois ils peuvent se déguiser comme Lady Gaga). Além de modalizações deônticas da ordem dever, há também modalizações deônticas da ordem da interdição, que exprimem atitudes que o professor não deve tomar ( Tu n'as pas le droit de faire ça [se comporter comme un prof d'une salle commun]). Algumas escolhas lexicais associadas a modalizações também demonstram uma forma de se posicionar em relação ao que está sendo enunciado, e mostram aspectos de seu trabalho, como vemos em "je dois faire un miracle" e "tu dois avoir une baguette magique". Há o uso de termos que indicam coragem, sedução, motivação e empatia com os alunos por meio das seguintes construções: "tu dois être courageux / on doit séduire tout le temps / on doit motiver / on doit se porter comme un élève / je dois gagner la salle". Outras 
escolhas lexicais que chamam a atenção em nossa análise são aquelas feitas pelo professor para designar a si mesmo em seu trabalho: "un magicien, un séducteur, un présentateur d'un débat", são termos que indicam os papéis assumidos pelo professor no intuito de conseguir exercer de modo satisfatório seu trabalho.

A análise das verbalizações da professora $\mathrm{C}$ mostra igualmente as modalizações deônticas da ordem do dever, e as ações sobre as quais elas incidem demonstram a preocupação em seguir o cronograma (on doit continuer notre chronogramme), em trazer e aplicar atividades extras (tu dois apporter une activité plutôt culturelle) e passar o conteúdo necessário (je dois être technique et faire les élèves apprendre le contenu), assim como versam sobre a organização da sala (tu dois partager la salle en groupes). Em certos momentos, a professora associa as modalizações a sua própria ação, o que pode mostrar uma reflexão a respeito de seu trabalho (je dois parler de ce contenu-là / je dois arriver à la fin de la leçon x), mas também mostram, em outro momento, que o processo de reflexão progrediu para uma tomada de consciência e abertura para novas possibilidades em seu agir (j'ai découvert ce semestre que les élèves doivent être traités de manière différente / on doit penser un peu à ça [intégrer la salle, écouter les élèves] et moins au contenu).

\section{Discussão dos resultados}

Antes de nos atermos à discussão dos resultados, é importante esclarecer que os três documentos analisados têm relações diferentes com os contextos de trabalho estudados. A Resolução SE aplica-se aos CEL e o Guide du Moniteur aplica-se aos Cursos de Extensão. O CECR, no entanto, se configura como o documento mais geral entre os três analisados, já que se aplica aos dois contextos e, por seu conteúdo e abrangência, pode servir de inspiração inclusive para a formulação de outros documentos prescritivos, como é o caso do Guide du Moniteur.

1. Com quais orientações, implícitas e explícitas, deparam-se os professores de FLE em seus respectivos contextos de trabalho?

As análises mostram que os professores lidam com prescrições diversas em seu contexto de trabalho. Em relação aos documentos, notamos que eles têm pouca relação com a atividade quotidiana do professor. No que se refere à análise dos documentos, 
percebe-se que alguns deles, como a Resolução SE, encontram-se distantes da realidade do professor e não contemplam as dificuldades enfrentadas em suas situações de trabalho. O CECR, por sua vez, possui uma relação igualmente indireta com o trabalho dos professores, já que as orientações são diluídas e fluidas. O Guide du Moniteur é o documento que tem uma relação mais estreita com o trabalho dos professores-monitores dos Cursos de Extensão, visto que ele contempla aspectos do quotidiano e orienta pontualmente a atividade dos professores.

No caso das instruções ao sósia, notamos algumas prescrições explícitas e implícitas. Ao inserir a voz da coordenação em seu discurso, os dois professores mostram que tais instâncias prescrevem ações para o seu trabalho, seja mais explicitamente - "il faut parler français" - ou implicitamente, já que no caso dos Cursos de Extensão a coordenação parece atuar como instância avaliadora do que é feito pelos professores e, nesse caso, prescreve indiretamente. É pensando nessa avaliação que a professora Carina organiza sua atividade. Além de tais prescrições, percebe-se também uma carga considerável de autoprescrição feita pelos professores. O professor J, por exemplo, sente a necessidade de ter uma postura autônoma em seu trabalho por causa da carência de orientações, material e formação, por isso, ele se autoprescreve as formas de lidar com os alunos (necessidade de cativá-los, motivá-los, ganhar a sala), com os equipamentos (é necessário testar antes de usar e improvisar caso não funcione, fazer um milagre, ter uma baguete mágica). A professora $\mathrm{C}$, por sua vez, concentra suas preocupações com o conteúdo, com o cronograma do curso e com a gestão da sala de aula.

2. Como os professores veem a si mesmos enquanto docentes? E como veem seu próprio trabalho?

É perceptível que os dois professores têm a consciência de que são iniciantes no métier, mas só a professora $\mathrm{C}$ o expressa em sua fala ao inserir a voz desse professor iniciante (on apprend à donner des cours). $\mathrm{O}$ grau de autonomia exigido do professor $\mathrm{J}$ em seu contexto de trabalho faz com que ele tenha consciência de que é necessário que ele seja mais que um professor, já que em certos momentos notamos, pelas escolhas lexicais, que ele refere-se a si mesmo como um mágico, um sedutor, um apresentador de debate. É por esse contexto de falta e dificuldade que o professor assume um posicionamento de valorização do trabalho dos professores (Je travaille bien, je suis un 
bon professeur et vais être bien payé), mas por vezes se percebe desanimado em relação a seu trabalho (il nous manque toujours quelque chose [...] une chose [...] qui me donne envie d'abandonner ma profession). Podemos inferir que o professor $\mathrm{J}$ procura se distanciar do que ele chama de "professor de uma sala comum", o que denota que há uma consciência da diferença percebida entre seu trabalho (ensino de francês para adolescentes em um curso livre) e o trabalho de professores do ensino regular.

As preocupações da professora $\mathrm{C}$ condizem com sua visão de si mesma como iniciante. Por fazer parte de um contexto de trabalho que é amparado pelos pares e pela coordenação, suas preocupações se voltam para sua organização pessoal e gestão de suas turmas. A partir de uma reflexão, ou tomada de consciência, a professora percebe outras formas de fazer seu trabalho. Nota-se que, pelo processo de intervenção, a professora tomou distanciamento de si mesma e pôde visualizar novas formas de agir (CLOT, 2001).

3. Qual a relação entre o que está prescrito nos documentos e a forma como os professores veem a si mesmos e a seu próprio trabalho?

Não há uma relação direta entre o que está prescrito nos documentos inerentes ao contexto de trabalho dos CEL e o trabalho do professor. Percebe-se, portanto, que há uma carência de orientações em relação às dificuldades enfrentadas. No entanto, existe uma relação indireta que se estabelece entre o que está posto na Resolução SE e a forma como professor $\mathbf{J}$ vê a si mesmo. Ao retomarmos as vozes inseridas no trecho analisado da Resolução SE, notamos que há uma voz teórica geral que abarca as áreas da sociologia e da pedagogia. As observâncias que se faz ao professor, sobretudo com a voz da sociologia, podem não ter chegado diretamente ao professor $\mathrm{J}$, mas provavelmente são tópicos de discussão entre os professores, a coordenação pedagógica, nas reuniões da escola e mesmo por observações pontuais que se faz a respeito das atribuições de um professor. Isso parece afetar de certa forma o professor Jean, já que ele, ao enxergar-se em seu trabalho, atribui-se papéis além dos de professor - o de um sedutor, um mágico, um animador. Seduzir, cativar, ganhar o público parecem ser atribuições que o professor se dá para ir de encontro a elementos requeridos em documentos oficiais, e que indiretamente lhe alcançam, lhe afetam. Nesse caso, podemos considerar que o que está preconizado nos documentos oficiais faz parte da rede discursiva que permeia o trabalho do professor, e é por analisar essa rede 
discursiva que entendemos os efeitos das orientações no trabalho do professor $\mathbf{J}$. Bronckart e Machado esclarecem que "é a análise dessa rede que pode nos levar a uma compreensão maior das relações linguagem / trabalho" (BRONCKART; MACHADO, 2004, p. 135).

A professora C se percebe como parte de um grupo de professores que, conforme mostrado na análise dos documentos, se ajuda e se apoia. No entanto, os dados contextuais da produção do Guide du Moniteur indicam que o fato de ser um monitor mais experiente que elaborou e faz atualizações no documento, estabelece um padrão a ser alcançado pela professora C. O conjunto de orientações que compõem o documento parece nos mostrar um intuito de que as coisas sejam feitas da melhor maneira possível. Se, por um lado, isso ampara o professor, para a professora $\mathrm{C}$ parece ser também uma fonte de autocobrança e estresse, uma vez que ela fará de tudo para atender as expectativas de seus alunos e também de seus pares, alcançando esse ideal de organização. A partir da tomada de consciência e a visualização de novas possibilidades, o padrão que ela deseja alcançar perde força e importância, já que ela começa a vislumbrar novas possibilidades em seu agir docente. Nesse sentido, a instrução ao sósia parece ter cooperado para que a professora ampliasse seu poder (CLOT, 2001) de agir a partir da tomada de consciência.

\section{Conclusões}

A partir dos pontos discutidos neste artigo, podemos concluir que existe uma relação, ainda que não explícita, entre as prescrições presentes nos documentos e o trabalho do professor. O que mais nos chama a atenção, no entanto, é o distanciamento que tais documentos têm em relação à atividade quotidiana dos professores. Salvo em alguns casos, no caso o Guide du Moniteur, as orientações contidas nos documentos não dão conta de tratar das dificuldades específicas vividas nas situações de trabalho.

É por meio das verbalizações feitas pelos professores que podemos identificar as prescrições explícitas e implícitas que permeiam seu trabalho, sendo que tais orientações podem vir da coordenação de uma forma direta ou indireta. As autoprescrições podem indicar que o professor, na ausência de orientações, preenche essa lacuna. As verbalizações mostraram também que o uso da instrução ao sósia como método de intervenção no trabalho propiciou, em primeiro lugar, um distanciamento dos professores em relação ao próprio trabalho (CLOT, 2001) e uma posterior tomada de 
consciência, o que, por sua vez, levou à visualização de novas possibilidades de agir, o que parece indicar um aumento no poder de agir dos professores por meio do uso desse método (CLOT, 2001).

Nesse sentido, parece-nos que a instrução ao sósia pode ser um importante método para a formação de professores, pois permite o distanciamento dos professores e de sua atividade de trabalho, fazendo com que reflitam sobre ele e encontrem outras maneiras de agir. Apontamos, também, a possibilidade de continuidade de pesquisas que envolvam um contexto pluriinstitucional, o que pode promover ricas discussões e novas possibilidades na área de formação de professores.

Por fim, ressaltamos a importância dos contextos dos centros de línguas públicos para a formação de jovens professores, pois eles permitem aprender a profissão no e pelo trabalho, sendo, no caso dos cursos de extensão ligados à universidade, um verdadeiro locus de aprendizagem do métier de professor.

\section{REFERÊNCIAS}

AMIGUES, R. Trabalho do professor e trabalho de ensino. In: MACHADO, A. R. (Org.) $\mathrm{O}$ ensino como trabalho: uma abordagem discursiva. Londrina: Eduel, 2004.

AMIGUES, R. L'enseignement comme travail. In: BRESSOUS, P. (Org.) Les stratégies de l'enseignant en situation d'interaction. Note de synthèse pour Cognitique: Programme École et Sciences Cognitives, p. 243-262, 2002.

AMIGUES, R. Pour une approche ergonomique de l'activité enseignante. Skholê, horssérie 1, p. 5-16, 2003.

\section{AUTHIER-REVUZ, J. As não-coincidências do dizer e sua representação}

metaenunciativa: estudo linguístico e discursivo da modalização autonímica. Palavras incertas - As não coincidências do dizer. Campinas, SP: Editora da UNICAMP, 1998.

BRONCKART, J. P. Atividade de linguagem, textos e discursos: por um interacionismo sociodiscursivo. São Paulo: Educ, 1999.

BRONCKART, J. P. Atividade de linguagem, discurso e desenvolvimento humano. Campinas: Mercado de letras, 2006.

BRONCKART, J.-P. O agir nos discursos: das concepções teóricas às concepções dos trabalhadores. Campinas: Mercado de Letras, 2008.

BRONCKART, J. P. Evolutions récentes de la conception et du statut des genres textuels dans la perspective de l'ISD. Genève, Université de Genève, 2013. Notes de présentation de la Conférence Activités, textes et langues: leur dymanique interactive et ses effets. 
BRONCKART, J. P.; MACHADO, A. R. Procedimentos de análise de textos sobre o trabalho educacional. In: MACHADO, A. R. (Org.) O ensino como trabalho: uma abordagem discursiva. Londrina: Eduel, 2004.

CLOT, Y. La fonction psychologique du travail. Paris: Presses Universitaires de France, 1999.

CLOT, Y. Méthodologie en clinique de l'activité: l'exemple du sosie. In: DELEFOSSE, M. S.; ROUAN, G. (Orgs.). Les méthodes qualitatives en psychologie. Paris: Dunod, 2001.

CLOT, Y. Travail et pouvoir d'agir. Paris: PUF. 2008, 296.

CONSEIL DE L'EUROPE. Cadre européen commun de référence pour les langues: Apprendre, Enseigner, Évaluer (CECRL), 2001. Disponível em: $<$ http://www.coe.int/t/dg4/linguistic/Source/Framework_fr.pdf $>$. Acesso em 31 de maio de 2013.

FAITA, D. Gêneros de discurso, gêneros de atividade, análise da atividade do professor. In MACHADO, A. R. O ensino como trabalho: uma abordagem discursiva. Londrina: EDUEL, 2004.

SÃO PAULO. Resolução n. 70, de 26 de outubro de 2010. Dispõe sobre os perfis profissionais, competências e habilidades requeridos dos educadores da rede pública estadual e os referenciais bibliográficos que fundamentam os exames, concursos e processos seletivos, e dá providências correlatas. Siau Edunet, São Paulo, 26 de out. de 2010. Disponível em: <https://goo.gl/qC7992>. Acesso em: 07 abr. 2013.

SAUJAT, F. O trabalho do professor nas pesquisas em educação: Um panorama. In: MACHADO, A. R. (org.). O ensino como trabalho: uma abordagem discursiva. Londrina: Eduel, 2004.

SAUJAT, F. Fonction et usages de l'instruction au sosie en formation initiale. Conférence à l'IUFM d'Aix-Marseille, 2005.

VIGOTSKI, L. La signification historique de la crise en psychologie. Lausanne, Paris: Delachaux et Niestlé., 1927/1999.

\section{Como referenciar este artigo}

MENEZES, Marcos da Costa.; LOUSADA, Eliane Gouvêa.. O trabalho do professor de francês como língua estrangeira: um estudo sobre as relações entre as prescrições e o que dizem os professores sobre seu trabalho. Rev. EntreLínguas, Araraquara, v.3, n.1, p. 35-56, jan./jun. 2017. Disponível em: <https://doi.org/10.29051/rel.v3.n1.janjun.2017.9638>. E-ISSN: 2447-3529.

Submetido em: 01/04/2017

Aprovado em: 24/05/2017 